\title{
A proposed an interactive reliable aggregated photovoltaic cell for a longer time solar energy extraction
}

\author{
EI Sayed Soliman, Hamdy Abd El-Halim, Amr Refky
}

Electrical Engineering Department, Faculty of Engineering, Al-Azhar University, Cairo, Egypt

\begin{abstract}
Article Info
Article history:

Received Oct 22, 2021

Revised Jan 24, 2022

Accepted Jan 31, 2022

\section{Keywords:}

Aggregated photovoltaic cell Interactive

Photovoltaic cell

Solar energy extraction

ABSTRACT

The higher solar energy urges to maximize the solar energy extraction and utilization. This paper aim is to propose a new technique for extending the daily extraction time via a proposed aggregated PV cell. This system idea is using group of the photovoltaic (PV) cells to behave as an interactive regulated cell according to the series or parallel connections, it can call it an aggregated cell. This can be realized by interactive switching system according to the single cell output voltage. Six $6 \mathrm{~V}$ PV cells are used for configuring the proposed single aggregated $6 \mathrm{~V}$ PV cell. The technique depends on both single-cell number and their interconnections pattern. Switching the panel connection between the fully series cells to full parallel ones according to either sunlight states or the single-cell output is automatically achieved using an interactive control system. This system includes a voltage sensor that implements the suitable switching pattern for the aggregated cell. The ripple voltages during both morning and afternoon low sun times, as well as due to any other reason such as the lower clouds are efficiently eliminated. The simulated and the experimental results show in a satisfactory agreement the proposed aggregated PV cell validation.
\end{abstract}

This is an open access article under the CC BY-SA license.

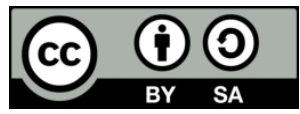

\section{Corresponding Author:}

Amr Refky

Electrical Engineering Department, Faculty of Engineering, Al-Azhar University

Al-Nasr Road, Nasr City, Cairo, P.O. 11751, Egypt

Email: amrrefky@azhar.edu.eg

\section{INTRODUCTION}

The sun is the main source of limitless and non-harmful energy. Solar heating, photovoltaic, solar thermal energy, solar architecture, molten salt power plants, and artificial photosynthesis are examples of everevolving technology. It is a vital renewable energy source, and its technologies are classified as passive or active depending on how they collect, distribute, or transform solar energy [1]-[3]. Active solar energy harvesting methods include photovoltaics, concentrated solar power, and solar water heating. Materials with high thermal mass or light dispersive characteristics are used in passive solar design, as are rooms that naturally circulate air [4], [5].

The massive amount of solar energy accessible makes it a very attractive source. The yearly solar energy potential was $1.575-49,837$ exajoules (EJ), which is many times the 2012 global energy usage of 559.8 EJ [6]. The sun is a major source of energy, which significantly surpasses any foreseeable energy needs. The cost and effectiveness of the technology are key considerations in harnessing these for energy [7], [8]. The sun produces energy by converting about $650,000,000$ hydrogen atoms into helium every second. The process generates heat and electromagnetic radiation. The sun's heat helps keep the thermonuclear process continuing. Various electromagnetic waves (visible, infrared, and ultraviolet) are released into space. Most of the sun's total radiation never reaches earth. Surviving radiation serves as an indirect source of nearly all energy utilized 
today [7]. Sunlight influences many natural movements (wind, wave, heat, and light). Converting these motions into electricity, the most useful type of energy, is a highly contested subject. Photosynthesis turns sunlight into biotic energy [9].

Active and passive solar energy can be generated. Most energy sources on earth are solar. Solar energy may be collected directly to produce power or heat using panels or mirrors. Photovoltaic cells turn darkness into energy. Solar thermal collectors heat water or structures using heat-absorbing panels and circulation tubes. Reflected sunlight is focused on a heat-collecting device by means of mirrors (parabolic troughs, huge circular dishes, or Fresnel lenses). Condensed solar energy warms water or a heat-transferring fluid like molten salt to produce steam, which is then utilized to spin turbines and create electricity. Passive techniques are used to manipulate solar energy without converting it to electricity. Using windows, skylights, sunrooms, building site and orientation, and thermal construction materials may successfully capture natural solar radiation. A welldesigned passive solar house lowers heating and cooling demands first through energy efficiency, then uses solar energy to match those lowered loads [10], [11].

\section{LITERATURE REVIEW RELATED RESEARCH}

\subsection{Solar radiation and solar energy conversion}

Maximum solar radiation reaches earth's surface at $1.0 \mathrm{~kW} / \mathrm{m}^{2}$ in the wavelength range $0.3-2.5 \mathrm{~m}$. This is infrared shortwave radiation. This flux ranges from 3 to $30 \mathrm{MJ} / \mathrm{m}^{2}$ day for inhabited regions depending on location, time and weather. A system for converting solar energy into thermal or electrical energy requires precise measurements of the local solar radiation and understanding of its characteristics. The sun-earth distance is $1.5 \times 10^{11} \mathrm{~m}$. In the solar core, the Risa thermonuclear fusion reactor. Its temperature is $(8-40)$ $106 \mathrm{~K}$. The temperature drops to $130,000 \mathrm{~K}$ at $0.7 \mathrm{R}$ from the Sun's core. The convection zone is 0.7-1.0 R. The surface temperature drops to $5000 \mathrm{~K}$ [10]. Conversion processes commonly associated with the sunshine: heliochemical, referring to photosynthesis, helioelectrical, used in solar cells (photovoltaic), heliothermal, which converts sunshine into thermal energy and is used in CSP facilities [11], [12].

\subsection{Photovoltaic solar energy conversion}

Solar cells convert sunlight into energy. Photovoltaic can convert both active and passive solar energy. The efficiency of solar energy conversion into electricity varies between $7 \%$ and $40 \%$ depending on the semiconductor material used to build the cells [13]-[16]. Solar energy can be commercially utilized in two major ways: By using the photovoltaic effect, and by thermal conversion. These include solar water heating, passive solar heating and cooling, and solar photovoltaic energy generation. Variety of energy sources is used by industry to increase efficiency. Developers and utilities are also using solar photovoltaic (including concentrated photovoltaic) and other concentrating solar power technologies to power cities and small towns [17]-[19]. Most solar cells are silicon-based. After a while, the electrons are freed from their atoms and may travel freely through the substance. The DC energy is then transferred through a power converter to be converted to AC electricity, which is supplied to homes and businesses. There are three types of silicon used in PV cells: crystalline, polycrystalline, and amorphous [20]. PV and solar thermal systems may be combined. A concentrated photovoltaic thermal (CPVT). Several CPVT systems have been developed, researched, and experimentally demonstrated. Due to its unique characteristics, PVT systems have a great potential for market penetration in the energy industry [21]-[24].

The sun radiance hours per day is differ from place to another depending on the location on the planet, but all have almost the same profile. Many researches pay high attention to estimate and measure this profile for different places to have a clear and accurate information in order to reach optimum design criteria for new solar energy stations [25]-[27]. Figure 1 shows the sun irradiance profile, which illustrate that early morning hours and at the day end hours the sun irradiance is exist but not sufficient for solar energy conversion, the main goal of this work is to extract the useful daily sun irradiance hours as possible.

\subsection{Problem definition}

The average daily solar insolation in units of $\mathrm{kWh} / \mathrm{m}^{2}$ per day is sometimes referred to as "peak sun hours". The term "peak sun hours" refers to the solar insolation which a particular location would receive if the sun were shining at its maximum value for a certain number of hours as shown in Figure 1 [28]. Yearly sun radiation profile in different months is shown in Figure 2. This research proposes an interactive aggregated PV cell to extend the extraction time based on utilizing multi-PV cells. The rated aggregated PV cell output voltage will be obtained at about one-sixth of the single cell rated voltage. This can extend the extraction time to around $30 \%$ of the peak extraction time. Furthermore, days grow shorter, and the intensity of the sun drops $5 \mathrm{x}$ from summer to winter in northern latitudes [29]. This is another relevant reason for searching the alternatives of the traditional PV solar energy extractors. 


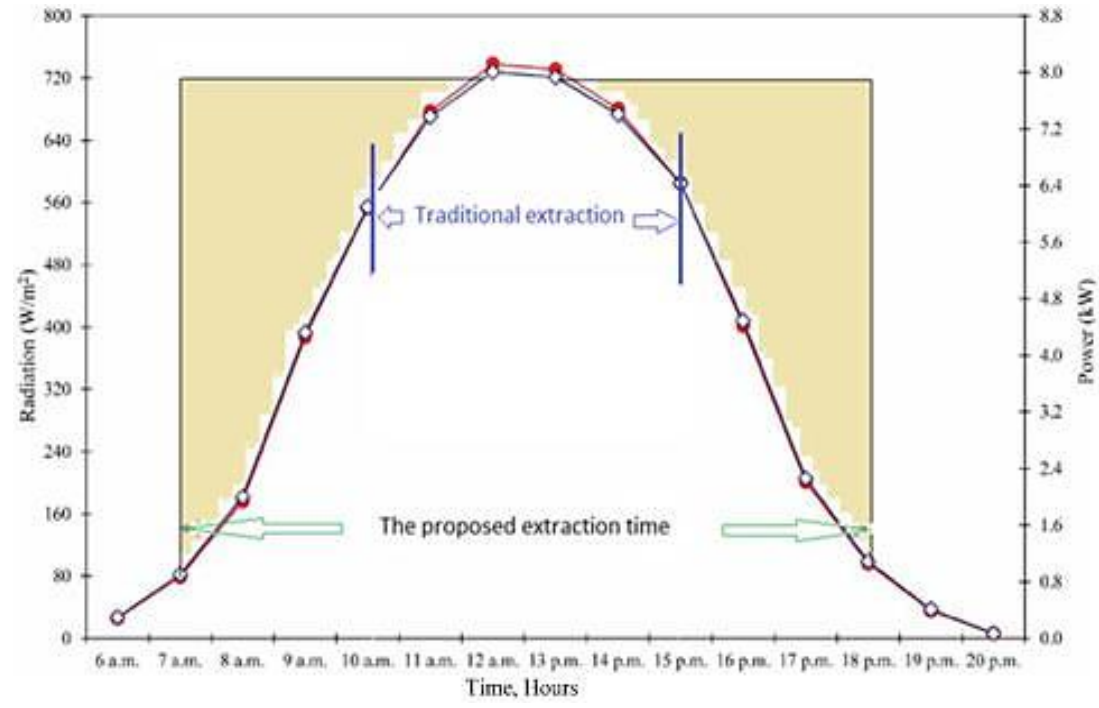

Figure 1. Dailly sun irradiance profile

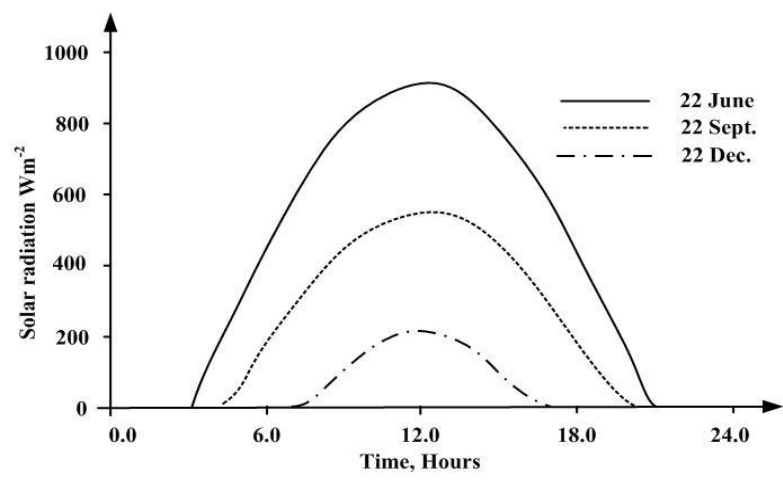

Figure 2. Yearly sun irradiance profile

\section{A PROPOSED INTERACTIVE AGGREGATED PV CELL FOR LONGER TIME OF SOLAR ENERGY EXTRACTION}

According to the daily sun profile mentioned in (problem definition), this work proposes a scheme that can extend the extraction time for about $30 \%$ of the peak extraction time. This is achieved by using limited number $(3,6,9$ or 12) single PV cells for configuring a single aggregated PV cell. The number of these single cells and their connection depend on rated single cell output voltages. For instance, PV cell of $6 \mathrm{~V}$ rated output voltage, one can use 6 cells for configuring the interactive aggregated PV cell. Based on sunlight states the six cells will be switched from all series connected to all parallel connected for configuring the aggregated cell. Nevertheless, the broadly system block diagram is shown in Figure 3, that includes the aggregated cell, voltage regulation unit, and the interactive switching unit.

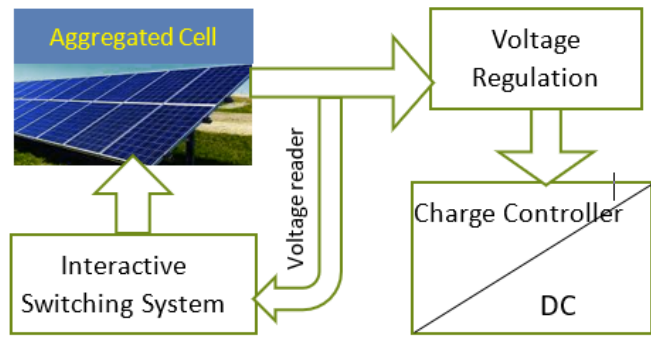

Figure 3. The proposed system block diagram 


\subsection{System operational scenarios}

This work presents four different scenarios in addtion to the night (dark) one that disconnects the aggregated cell as shown in Figure 4. This case is the open circuited cells with an aggregated cell output voltage is zero. However, driving the fifteen switches of operational scenarios is via the microcontroller (GPIO) output ports. One of the microcontroller analog input port is assigned to read a single cell output voltage. According to voltage level of this single cell output voltage, the desired operational scenario will be implemented.

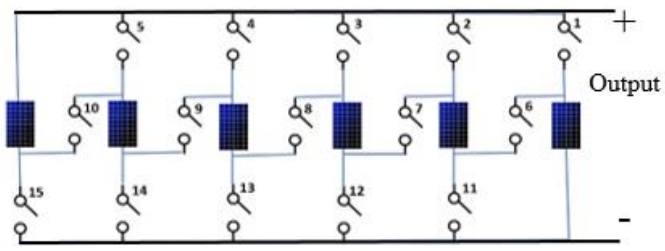

Figure 4. Night/dark connection of the aggregated PV cell circuit diagram

\subsection{First mode: start-up mode 6 Series connected cells single branch (single aggregated cell)}

Whenever the single cell output voltage reaches $1 \mathrm{~V}$ the system will automatically turn ON and all six cells will be in series connected resulting in $6 \mathrm{~V}$ output voltage of the aggregated cell. These connections of Figures 5 (a) and 5 (b) are remaining until the single cell output voltage reaches about or close to $2 \mathrm{~V}$. This is therefore causing that the aggregated output voltage will be very close to about $12 \mathrm{~V}$ as shown in Figure 6 . This leads the control circuits for renew the switching pattern according to the algorithm of Figure 6 . to the second switching pattern as shown in Figure 7.
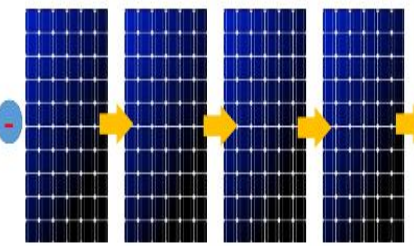

(a)

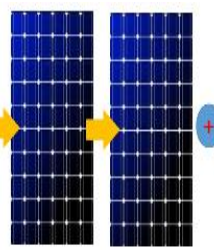

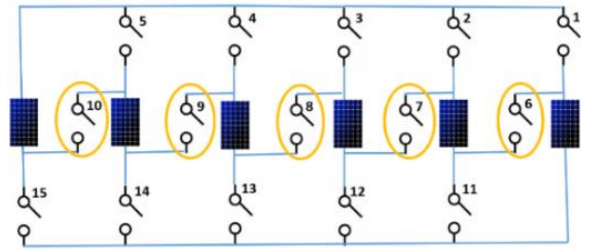

(b)

Figure 5. Six series connected cells (single aggregated cell) to (a) six series connected cells (single aggregated cell) and (b) switching pattern

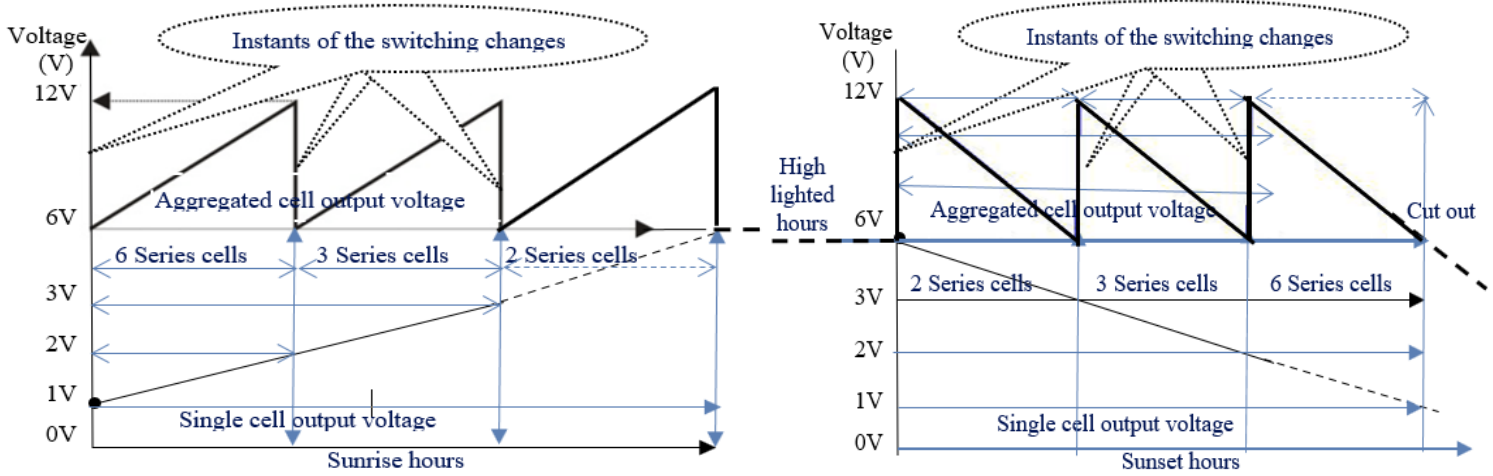

Figure 6. The output voltage of both the single and aggregated cells (day hours)

The output voltage of the aggregated cell is obtaining from (1).

$$
V_{A G G_{-} C E L L}=V_{C E L L_{-} 1}+V_{C E L L_{-} 2}+\ldots+V_{C E L L_{-} 6}
$$


Where $V_{A G G_{-} C E L L}$ is the aggregated cell output voltage and $V_{C E L L_{-} l}$ is the first single cell output voltage. Furthermore, this aggregated output voltage is determined by:

$$
\begin{aligned}
& V_{o}=V_{A G G_{-} C E L L}=6 \times\left(V_{C E L L_{-} 1}\right) \\
& I_{o}=I_{\text {cell }}
\end{aligned}
$$

Where output current equals the single cell current $I_{\text {cell }}$

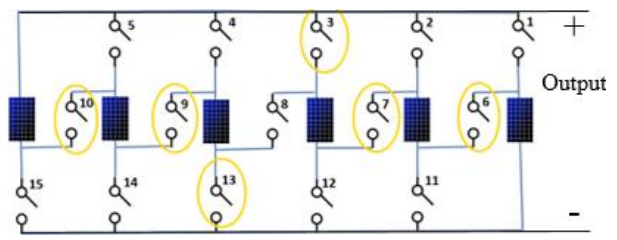

Figure 7. Three series connected cells in two parallel branches (single aggregated cell)

\subsection{Second mode: three series connected cells-two parallel branches}

During the second switching state, the control circuits is automatically switching the cells interconnection to be three series connected cells in two parallel branches single aggregated cell as shown in Figure 7, this state is staying until the single cell output voltage growth to be around $3 \mathrm{~V}$. The aggregated output voltage is then reaching around $9 \mathrm{~V}$ while the regulation unit will keep the output about $6 \mathrm{~V}$. In this scheme the aggregated output voltage can found from (4), while the output power will reach the twice the single cell output power.

$$
\begin{aligned}
& V_{o}=V_{A G G_{-} C E L L}=V_{C E L L_{-} 1}+V_{C E L L_{-} 2}+V_{C E L L_{-} 3} \\
& I_{o}=2 \times I_{\text {cell }}
\end{aligned}
$$

\subsection{Third mode: two series connected cells in three parallel branches (single aggregated cell)}

During the third mode (two series connected cells-three parallel branches) as shown in Figure 8, the aggregated cell output voltage can reach about $12 \mathrm{~V}$ at the output of the single is just before its rated $6 \mathrm{~V}$. At this instant the single cell output is typically equal the aggregated cell output voltage. The aggregated cell output voltage can be calculated according to (4), resulting in an output power of triple the output of the single cell output power.

$$
\begin{aligned}
& V_{o}=V_{A G G_{-} C E L L}=V_{C E L L_{-} 1}+V_{C E L L_{-} 2} \\
& I_{o}=3 \times I_{\text {cell }}
\end{aligned}
$$

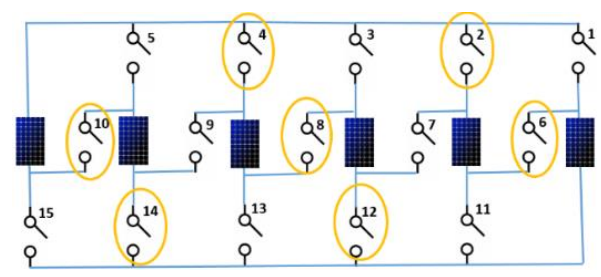

Figure 8. Three parallel branches-two series cells (each)

\subsection{Fourth mode: single cell-six parallel branches (aggregated cell)}

This is, indeed, the default operational mode that is offering an output of $6 \mathrm{~V}$ at six times of power as shown in Figures 9 (a) and (b). The salient feature of this system is the capability to start earlier as well as staying for longer time of energy extraction compared with the traditional connection of the PV cells. Moreover, it can significantly overcome most of negative effects of the environmental parameters such as the lower clouds and dusty wind. The output voltage of the aggregated cell is typical as the single cell voltage at hexa-times of the output power, the output is therefore obtaining from the next (9). 
$V_{o}=V_{A G G_{-} C E L L}=V_{C E L L_{-} 1}$

$I_{o}=6 \times I_{\text {cell }}$

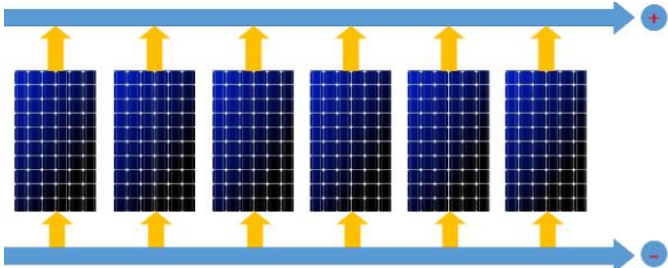

(a)

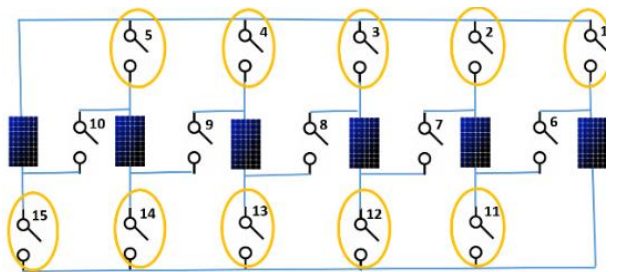

(b)

Figure 9. Fully paralleled cells arrangement to (a) fully parallel connected cells and (b) switching pattern

\subsection{Voltage regulation}

As depicted throughout the four operation modes of the proposed aggregated cell, the output voltage is varying between the single solar cell rated value $(6 \mathrm{~V})$ and the twice rated value $(12 \mathrm{~V})$. Voltage regulation is therefore essentially required for fixed output voltage during the whole extraction time. This work design and implement the circuit shown in Figure 10 that fixes the aggregated cell output voltage at around $6 \mathrm{~V}$ along the whole solar energy extraction time.

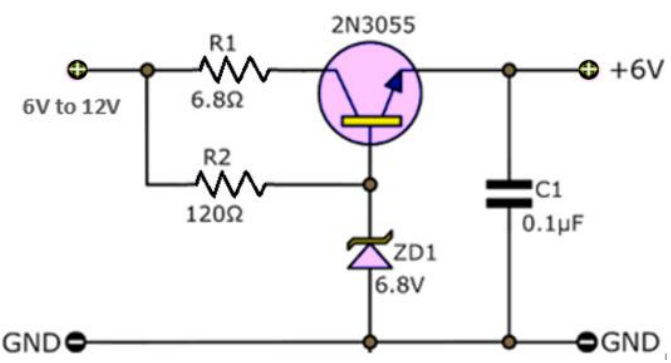

Figure 10. Voltage regulator circuit diagram

\subsection{Proteus simulation}

A simple proteus model is developed for simulating the proposed aggregated cell as shown in Figure 11. An opto-isolators are used as glue circuits between the digital (microcontroller) and the power (PV connected to relay) circuits.

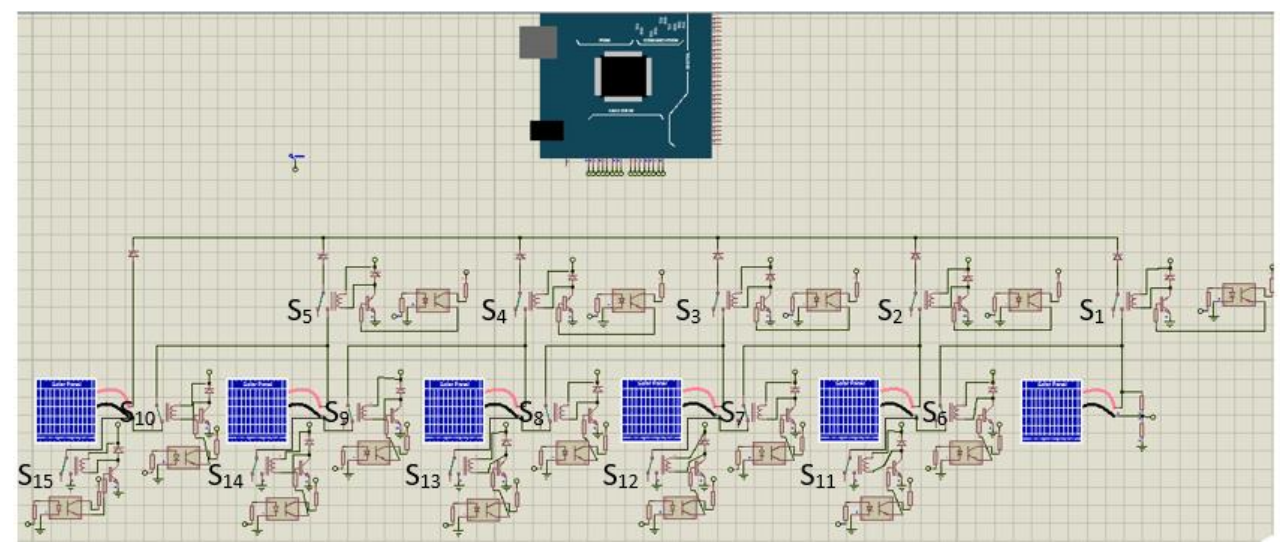

Figure 11. An aggregated cell using porteous package 


\section{EXPERIMENTAL WORK AND RESULTS}

This work uses six monocrystalline photovoltaic cells that are $6 \mathrm{~V}$ rated output voltage for configuring the proposed aggregated PV cell. Microcontroller Atmega32 is accompanied with the low-cost glue circuits for firing the switching circuit according to the output voltage of the single cell shown in Figure 12 (a). The 15 switches of the switching module shown Figure 11 are experimentally arranged and configured as shown in Figure 12 (b). In the following sections, some operational scenarios will be discussed.

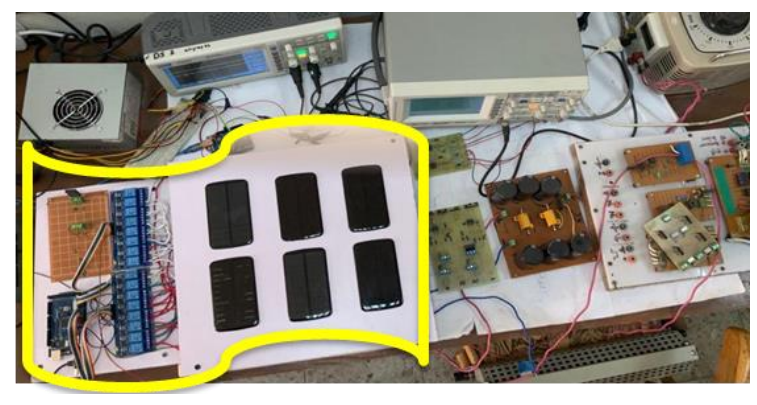

(a)

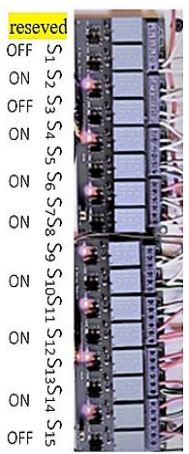

(b)

Figure 12. laboratory setup system (a) whole system and (b) interactive switches

\subsection{Unregulated output of the aggregated cell}

The unregulated output voltage of the first operational mode the aggregated cell that all are in series connected; five switches $\left(\mathrm{S}_{6}, \mathrm{~S}_{7}, \mathrm{~S}_{8}, \mathrm{~S}_{9}\right.$ and $\mathrm{S}_{10}$ are $\left.\mathrm{ON}\right)$ is displayed in Figure 13. This unregulated output voltage can cause undesired load disturbances. However, these voltage ripples are inhibited by using high current voltage regulator.

\subsection{Regulated output of the aggregated cell}

In the following paragraph, different outputs for the proposed aggregated cell at different operational scenarios, for example the regulated output of the second mode; two parallel branches with three series connected cells via turning ON the switches $\left(S_{3}, S_{6}, S_{7}, S_{9}, S_{10}\right.$ and $\left.S_{13}\right)$ as shown in Figure 14. The aggregated cell output voltage $(6.2 \mathrm{~V})$ is remaining close to $6 \mathrm{~V}$.

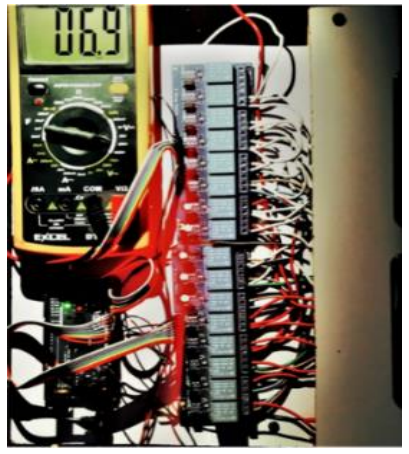

Figure 13. First mode unregulated output voltage of the fully series connected cells

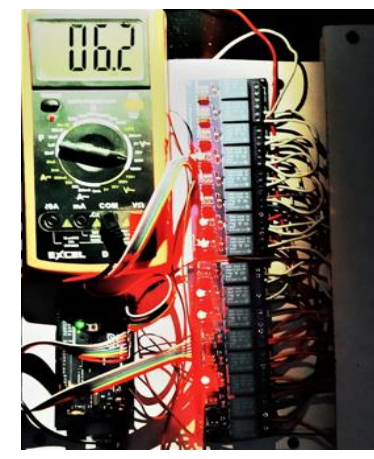

Figure 14. Output voltage of two parallel branches three series connected cells

\subsection{Third operational mode}

The third operational mode where, three parallel branches; two series connected cells for each. This mode is activated due to $3 \mathrm{~V}$ output voltage for any of the single cells. In spite of an expected $12 \mathrm{~V}$ output voltage of the aggregated cell, the laboratory regulated output voltage of Figure 15 is depicted in Figure 16. 


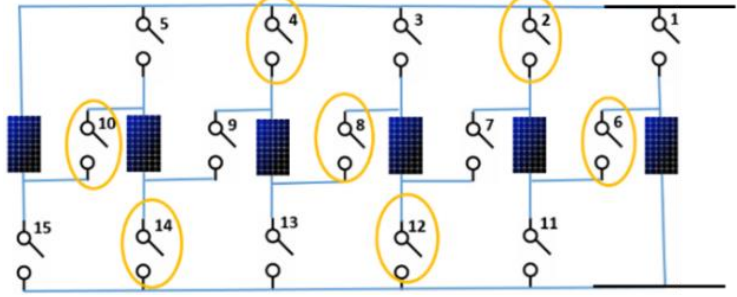

Figure 15. Third mode of the switching module (7 switches are $\mathrm{ON}$ )

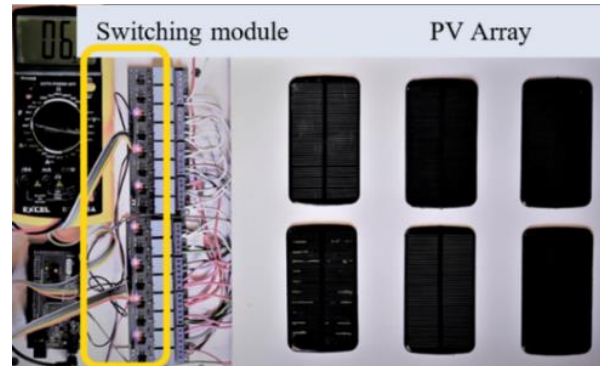

Figure 16. Experimental third mode of the switching module (7 switches are $\mathrm{ON}$ )

\subsection{Fourth operational mode}

Finally, the last mode that all 6 parallel connected cells where the switches $\left(S_{1}, S_{2}, S_{3}, S_{4}, S_{5}, S_{11}, S_{12}\right.$, $\mathrm{S}_{13}, \mathrm{~S}_{14}$ and $\mathrm{S}_{15}$ are $\mathrm{ON}$ ) as shown in Figure 17 with output voltage 6.1 V. During this mode each single cell operates at rated output $6 \mathrm{~V}$. This means that the output power will be six times higher the traditional utilization of PV cell.

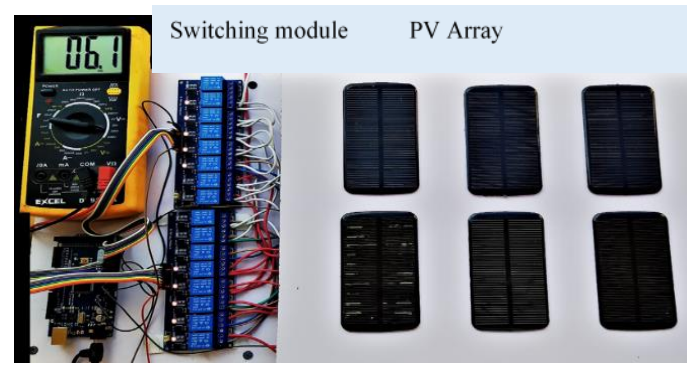

Figure 17. Output of six parallel connected cells (regulated)

\subsection{System validation}

The previous operational modes validate the suggested system where the rated output voltage of the interactive aggregated cell $6 \mathrm{~V}$ has been obtained earlier 1.5 hours than the traditional single cell techniques during sunrise state. While during the sunset state it stay for about 1.5 hours later than the conventional solution. About three hours are added to 6 hours of the traditional solar energy extraction techniques. These results are totally depending on several environmental parameters such as the lower clouds, fog, dust, and the ambient temperature in addition to the year seasons that have also significant effects. The system reliability can be considered the salient feature where it has stable and constant output voltage for wide range of power extraction.

\section{CONCLUSION}

Interactive aggregated PV-Cell based on four different operational modes have been proposed, developed, and implemented. The switching pattern is realized using microcontroller in addition to an interface circuit. These circuits have been offered in addition to the voltage regulation, it provided a suitable protection between the digital and the power sides using optocouplers isolators. Simple simulation model for the aggregated cell has been presented. The system results confirm that the aggregated output voltage can be successfully used whenever the single cell output voltage is around $1 \mathrm{~V}$. This can increase solar energy reliability and utilization against the lower clouds and both intervals of the sunrise and sunset lower irradiation. This system is significantly recommended for the unpredictable climate locations.

\section{ACKNOWLEDGEMENTS}

Authors are pleased to thank Eng. Zahraa Mahmoud Ali Saleh for her logistical support and laboratory tests. 


\section{REFERENCES}

[1] K. Saidi, M. Maamoun, and M. Bounekhla, "A new high performance variable step size perturb-and-observe MPPT algorithm for photovoltaic system," in International Journal of Power Electronics and Drive Systems (IJPEDS), vol. 10, no. 3, pp. 1662-1674, September 2019, doi: 10.11591/ijpeds.v10.i3.pp1662-1674.

[2] T. J. T. Ugli, "The Importance of Alternative Solar Energy Sources and the Advantages and Disadvantages of Using Solar Panels in this Process," in American Journal of Software Engineering and Applications, vol. 8, no. 1, 2019, pp. 32-35. doi: 10.11648/j.ajsea.20190801.14

[3] S. Miqoi, A. E. Ougli, and B. Tidhaf, "Adaptive fuzzy sliding mode based MPPT controller for a photovoltaic water pumping system," in International Journal of Power Electronics and Drive System (IJPEDS), vol. 10, no. 01, March 2019, pp. 414-422, doi: 10.11591/ijpeds.v10.i1.pp414-422.

[4] M. A. Green, "Clean Electricity from Photovoltaics," in Photoconversion of solar Energy, United Kingdom: Imperial Collage Press, 2001.

[5] U. Eicker, R. Nouvel, E. Duminil, and V. Coors, "Assessing passive and active solar energy resources in cities using 3D city models," in Energy Procedia, vol. 57, pp. 896-905, 2014, doi: 10.1016/j.egypro.2014.10.299.

[6] United Nations Development Programme, "Energy assessment and challenge of sustainability," World Energy Assessment, Bureau for Development Policy, New York, 2000.

[7] M. S. Guney, "Solar power and application methods," in Renewable and Sustainable Energy Reviews, vol. 57, 2016, pp. 776-785, doi: 10.1016/j.rser.2015.12.055.

[8] M. S. Güney, K. Kaygusuz, "Hydrokinetic energy conversion systems: A technology status review," in Renewable and Sustainable Energy Reviews, vol. 14, no. 9, 2010, pp 2996-3004. doi: 10.1016/j.rser.2010.06.016.

[9] M. P. Johnson, "Photosynthesis," Essays in Biochemistry, vol. 60, no. 3, pp. 255-273, October 2016, doi: 10.1042/EBC20160016.

[10] "Passive Solar Home Design," Accessed: Oct. 3, 2021. [Online]. Available: http://energy.gov/energysaver/articles/passive-solarhome-design

[11] I. Bostan, A. Gheorghe, V. Dulgheru, I. Sobor, V. Bostan, and A. Sochirean, "Resilient Energy Systems Renewable: Wind, Solar, Hydro," Springer Dordrecht Heidelberg, 2013, doi: 10.1007/978-94-007-4189-8.

[12] A. C. Köberle, D. E. H. J. Gernaat, and D. P. van Vuuren, "Assessing current and future techno-economic potential of concentrated solar power and photovoltaic electricity generation," in Energy, vol. 89, pp 739-756, Sep 2015, doi: 10.1016/j.energy.2015.05.145.

[13] A. Abdulmula, K. Sopian, L. C. Haw, and A. Fazlizan, "Performance evaluation of standalone double axis solar tracking system with maximum light detection MLD for telecommunication towers in Malaysia," in International Journal of Power Electronics and Drive Systems (IJPEDS), vol. 10, no. 1, pp. 444-453, March 2019, doi: 10.11591/ijpeds.v10.i1.pp444-453.

[14] D. Zhang, F. Wang, R. Burgos and D. Boroyevich, "Common mode circulating current control of interleaved three-phase two-level voltage-source converters with discontinuous space-vector modulation," in IEEE Energy Conversion Congress and Exposition, 2009, pp. 2801-2807, doi: 10.1109/ECCE.2009.5316313.

[15] S. Kurtz, "Opportunities and challenges for development of mature concentrating photovoltaic power industry," National Renewable Energy Laboratory, Colorado, NREL/TP-5200-43208, 2011

[16] A. Makki, S. Omer, and H. Sabir, "Advancements in hybrid photovoltaic systems for enhanced solar cells performance," in Renewable and Sustainable Energy Reviews, vol. 41, pp. 658-684, 2015, doi: 10.1016/j.rser.2014.08.069.

[17] O. A. Elkholi, M. A. Enany, A. F. Abdo, and M. Eid, "Novel approach for SVPWM of two-level inverter fed induction motor drive," in International Journal of Power Electronics and Drive System (IJPEDS), vol. 11, no. 4, December 2020, pp. 1750-1758, doi: 10.11591/ijpeds.v11.i4.pp1750-1758.

[18] T. S. Liang, "A review of crystalline silicon bifacial photovoltaic performance characterisation and simulation," in Energy \& Environmental Science, vol. 12, no. 1, pp. 116-148, January 2019, doi: 10.1039/C8EE02184H.

[19] A. Makki, S. Omer, and H. Sabir, "Advancements in hybrid photovoltaic systems for enhanced solar cells performance," in Renewable and Sustainable Energy Reviews, vol. 41, 2015, pp. 658-684, doi: 10.1016/j.rser.2014.08.069.

[20] D. L. Talavera, P. Pérez-Higueras, J. A. Ruíz-Arias, E. F. Fernández, "Levelised cost of electricity in high concentrated photovoltaic grid connected systems: Spatial analysis of Spain,” in Applied Energy, vol. 151, pp. 49-59, 2015, doi: 10.1016/j.apenergy.2015.04.072.

[21] O. Z. Sharaf and M. F. Orhan, "Concentrated photovoltaic thermal (CPVT) solar collector systems: Part I - Fundamentals, design considerations and current technologies," in Renewable and Sustainable Energy Reviews, vol. 50, pp. 1500-1565, 2015, doi: 10.1016/j.rser.2015.05.036.

[22] O. Z. Sharaf and M. F. Orhan, "Concentrated photovoltaic thermal (CPVT) solar collector systems: Part II - Implemented systems, performance assessment, and future directions," in Renewable and Sustainable Energy Reviews, vol. 50, 2015, pp. 1566-1633, doi: 10.1016/j.rser.2014.07.215.

[23] "Solar Energy System Design" Accessed: Oct. 13, 2021. [Online]. Available: http://www.powerfromthesun.net/Book/chapter01/chapter01.html.

[24] H. Martín, J. la Hoz, G. Velasco, M. Castilla, and J. L. G. de Vicuña, "Promotion of concentrating solar thermal power (CSP) in Spain: Performance analysis of the period 1998-2013," in Renewable and Sustainable Energy Reviews, vol. 50, pp. 1052-1068, 2015, doi: 10.1016/j.rser.2015.05.062.

[25] A. H. Ali, A. S. Nada, and A. S. Shalaby, "Economical and efficient technique for a static localized maximum sun lux determination," in International Journal of Power Electronics and Drive System (IJPEDS), vol. 10, no. 2, June 2019, pp. 777-784, doi: 10.11591/ijpeds.v10.i2.pp777-784

[26] S. A. Jumaat and M. H. Othman, "Solar energy measurement using arduino," in MATEC Web of Conferences, vol. 150, pp. 1-6, 2018, doi: 10.1051/matecconf/201815001007.

[27] K. R. Ajao, R. M. Ambali, and M. O. Mahmoud, "Determination of the optimal tilt angle for solar photovoltaic panel in Ilorin, Nigeria," in Journal of Engineering Science and Technology Review, vol. 6, no. 1, pp. 87-90, 2013.

[28] A. Shiroudi, M. S. Deleuze, and S. A. Mousavifar, "Efficiency analysis of a solar photovoltaic array coupled with an electrolyser power unit: a case study," in International Journal of Ambient Energy, vol. 38, no. 3, pp. 240-249, 2017, doi: $10.1080 / 01430750.2015 .1086676$.

[29] "Light and the winter blues" Accessed: Oct. 13, 2021. [Online]. Available: https://www.sunlightinside.com/light-and-health/lightand-the-winter-blues/ 


\section{BIOGRAPHIES OF AUTHORS}
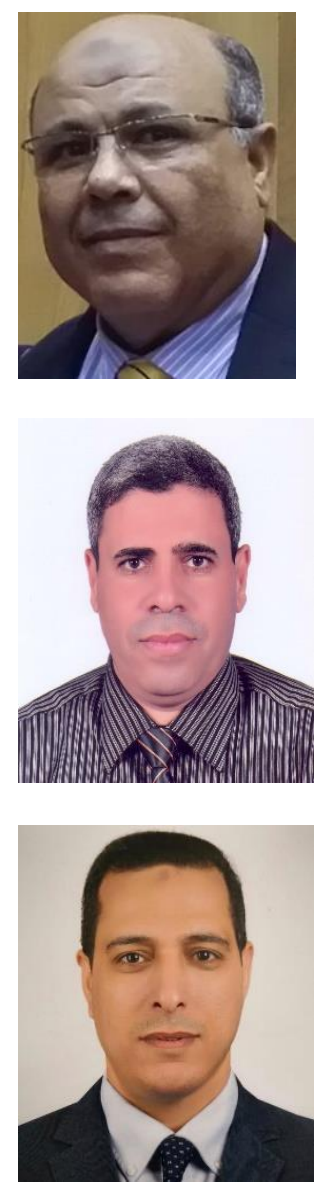

El Sayed Soliman (iD 81 SC $\mathrm{P}$ is an associate professor of Power Electronics. He was born in Ismailia, Egypt on December 09, 1959. He received the bachelor and master's degrees in electrical engineering from Al-Azhar University, Egypt in 1984 and 1990 respectively. His $\mathrm{PhD}$ degree in power electronics had been received in 1996 from Ghent University, Belgium. He has been the Head of the Research and Development Center RDC at Al-Ahsa college of technology, Saudi Arabia since 2001 up to 2013. His research interest is in area of the universal interactive RTC embedded systems, microcomputer-based systems, hybrid gridgreen sources technologies. He is a long-time designer for dynamic interfaces between the digital and electrical power sides. He can be contacted at email: elsoliman@azhar.edu.eg.

Hamdy Abd El-Halim (D) 8 SC P is an associate professor of Electric machines and drive at electrical engineering department, Faculty of engineering, Al-Azhar university, Cairo, Egypt, received BSc. degree in electrical Engineering from Shoubra Faculty of Engineering, Benha Branch, Zagazig University, 1992, MSc. from Al-Azhar university 2001, "Fuzzy Logic Speed Control of A Chopper Fed DC Motor", and PhD. Degree from Al-Azhar university 2006 "Analysis and Position control of stepper motor using Artificial Intelligence “. His research interest area is electrical machines and drive systems for different types of electrical machines as induction, stepper motors drives, linear induction motors, linear permanent magnet synchronous motor dive systems, Fuzzy and Neural control systems. He can be contacted at email: hamdyshatla.14@azhar.edu.eg.

Amr Refky (D) 8. SC $\mathrm{P}$ is a lecturer of Electric machines and drive at electrical engineering department, Faculty of engineering, Al-Azhar university, Cairo, Egypt, he received BSc. degree in electrical Engineering from Al-Azhar university 1999, MSc. from Tomsk poly technical university, Tomsk, Russia, 2009 in electric drive and complex system and PhD. from Tomsk poly technical university Tomsk, Russia, 2012 in electric complexes and systems. His research interest area is the drive systems for electrical machines as Permanent Magnet synchronous drive system, linear permanent magnet synchronous machine drives, direct torque control systems, field-oriented control systems. He can be contacted at email: amrrefky@azhar.edu.eg. 